\author{
Joanna Chłosta-Zielonka* \\ Uniwersytet Warmińsko-Mazurski w Olsztynie \\ https://orcid.org/0000-0001-8057-1898
}

\title{
O potrzebie powstania Słownika biograficznego pisarzy Warmii i Mazur od czasów najdawniejszych do współczesności
}

Streszczenie: Celem artykułu jest zwrócenie uwagi na potrzebę stworzenia Słownika biograficznego pisarzy Warmii i Mazur od czasów najdawniejszych do współczesności. Byłoby to kompendium wiedzy o pisarzach, którzy związani byli z terytorium dzisiejszej krainy Warmii i Mazur, zmieniającym swoje nazwy i oblicze przez wieki. Przedmiotem badań byliby zarówno ci autorzy, którzy mieszkając na tym obszarze tworzyli, jak i ci, którzy odwiedzając Warmię i Mazury, inspirowali się twórczo. Powstałe do tej pory leksykony i słowniki są niepełne, zawierają błędy merytoryczne, wymagają korekty i uzupełnień oraz poszerzenia o dużą liczbę haseł osobowych.

Słowa-klucze: Warmia i Mazury, słownik, biogram pisarza, bibliografia twórczości pisarzy.

Joanna Chłosta-Zielonka - dr hab., prof. UWM, pracuje w Katedrze Literatury Polskiej Instytutu Literaturoznawstwa Uniwersytetu Warmińsko-Mazurskiego w Olsztynie. Jest autorką dwóch monografii, m.in. Życie literackie Warmii i Mazur w latach 1945-1989 (2010), a także około 160 artykułów naukowych i recenzji publikowanych w tomach zbiorowych i czasopismach. 


\section{On the need to create a "Biographical dictionary of writers from Warmia and Mazury from the earliest times to the pre- sent day"}

Summary: The aim of the article is to draw attention to the need to create a "Biographical dictionary of writers of Warmia and Mazury from the earliest times to the present day". It would be a compendium of knowledge about writers who were associated with the territory of today's land of Warmia and Mazury, changing its names and face over centuries. The subject of research would be both those who visited the land and were creatively inspired. The lexicons and dictionaries created so far are incomplete, contain factual errors, require correction and supplementation, and need to be expanded with a large number of personal entries.

Key words: Warmia and Mazury, dictionary, biography of the writer, bibliography of writers' work.

Powojennym badaczom historii i piśmiennictwa Warmii i Mazur od początku przyświecała idea skatalogowania wiedzy o osobach, które przyczyniły się do rozwoju cywilizacyjnego tej krainy. W różnym czasie dopominali się o konieczność opisania warmińsko-mazurskiego kręgu pisarzy, stojący na czele środowiska literackiego: Władysław Gębik ${ }^{1}$, Władysław Ogrodziński²,

1 Władysław Gębik (1900-1986) - pedagog, pisarz, animator życia kulturalnego na Warmii i Mazurach. Był współorganizatorem Towarzystwa Wiedzy Powszechnej w Olsztynie, w latach 1950-1952 pełnił funkcję prezesa Zarządu tej organizacji. W latach 1952-1957 pracował w Państwowym Instytucie Sztuki jako kierownik Zespołu Terenowego; zajmował się zbieraniem i opracowywaniem regionalnego folkloru. Miał też duże zasługi przy powstawaniu olsztyńskiego środowiska literackiego. W grudniu 1952 roku był współzałożycielem „Słowa na Warmii i Mazurach”, regionalnego dodatku do gazety „Słowo Powszechne”, a następnie jego kierownikiem literackim. W 1953 roku uczestniczył w utworzeniu olsztyńskiego Klubu Literackiego, a w 1955 roku - Oddziału Związku Literatów Polskich; jego pracą kierował początkowo jako wiceprezes, a później prezes. Przewodniczył także Klubowi Literatury Regionalnej od chwili jego założenia. Szerzej: J. Chłosta, Warmiak z Podhala: Władysław Gębik pedagog, folklorysta, literat, Olsztyn 2006.

2 Władysław Ogrodziński (1918-2012) - historyk, autor powieści, reportaży, esejów i antologii, redaktor, edytor, organizator nauki i działacz kulturalny (pseud.: Stefan Sulima). W latach 
czy Edward Martuszewski, znany z kilku syntez porządkujących działalność literatów na Warmii i Mazurach ${ }^{3}$. Tworzyli kompendia wiedzy o twórcach, działaczach, osobistościach, bojownikach o polskość, wszystkich tych, którzy zaznaczyli swoją obecność na tej ziemi. Postulaty wcześniej wymienionych animatorów życia literackiego, zostały częściowo zrealizowane ${ }^{4}$, wciąż jednak brakuje publikacji bazowej, która stanowiłaby punkt wyjścia dla przyszłych badaczy. Każde istniejące już dzieło typu słownikowego nie zrealizowało w pełni postulatu badawczego, w taki sposób, w jaki zostało to sformułowane W zaproponowanym tytule artykułu. Stownik pisarzy Warmii i Mazur od czasów najdawniejszych do współczesności powinien być kompendium wiedzy o pisarzach, którzy związali się z terytorium dzisiejszej krainy Warmii i Mazur, zmieniającym swoje nazwy i oblicze przez wieki. W Słowniku zostaliby opisani zarówno autorzy, którzy mieszkając na tym obszarze tworzyli, jak i ci, którzy tylko odwiedzając Warmię i Mazury, inspirowali się twórczo. Zebrane w słowniku sylwetki pisarzy objęłyby okres od czasów najdawniejszych, tj. od

1956-1957 pracował jako adiunkt w Stacji Naukowej Polskiego Towarzystwa Historycznego w Olsztynie. Następnie kierował Wydziałem Kultury Prezydium Wojewódzkiej Rady Narodowej w Olsztynie (do 1960 r.). W tym czasie został aktywnym działaczem Towarzystwa Przyjaciół Mazurów i Warmiaków. W latach 1957-1983 był współzałożycielem i redaktorem „Rocznika Olsztyńskiego”, a od 1957 roku członkiem Rady Redakcyjnej „Komunikatów Mazursko-Warmińskich”. Do Związku Literatów Polskich należał od 1959 roku. Pozostawał także współzałożycielem, a potem dyrektorem programowym Stowarzyszenia Społeczno-Kulturalnego „Pojezierze” (1960-1962). W latach 1961-1962 zatrudniony był na stanowisku sekretarza generalnego, a w latach 1968-1970 dyrektora Ośrodka Badań Naukowych im. Wojciecha Kętrzyńskiego, którego był także współtwórcą. Po 1970 roku, do przejścia na emeryturę (31 grudnia 1983 r.), był dyrektorem Muzeum Warmii i Mazur w Olsztynie. Szerzej: J. Chłosta-Zielonka, Życie literackie Warmii i Mazur w latach 1945-1989, Olsztyn 2010, s. 304-312.

3 Edward Martuszewski (1921-1982) - dziennikarz i historyk, krytyk literacki i thumacz, wydał w porządku chronologicznym następujące prace dotyczące pisarzy związanych z Warmią i Mazurami w różny sposób i w różnym czasie: W oczach poetów: Warmia i Mazury 1945-1960, wybrał i oprac. E. Martuszewski, Olsztyn 1960; E. Martuszewski, Nawet kamień, Łódź 1965, tegoż, Mazury i Warmia w literaturze polskiej, Olsztyn 1966; Warmia i Mazury w oczach poetów 1940 1970, wybór i oprac. E. Martuszewski; Olsztyn 1972, Współcześni pisarze województwa olsztyńskiego, pod red. E. Martuszewskiego, Olsztyn 1972; E. Martuszewski, Polscy i niepolscy Prusacy: szkice z historii Mazur i Warmii, Olsztyn 1975.

4 Ten postulat spełniali badacze w kolejnych latach: m.in. Jan Chłosta, redagując Olsztyńskie biografie literackie (Olsztyn 1988), Joanna Chłosta-Zielonka, publikując monografię pt. Życie literackie Warmii i Mazur w latach 1945-1989 (Olsztyn 2010) oraz Joanna Szydłowska, wydając Narracje pojaltańskiego Okcydentu: literatura polska wobec pogranicza na przyktadzie Warmii i Mazur 1945-1989 (Olsztyn 2013). 
decyzji papieża Innocentego IV, który w 1243 wydzielił z obszarów dawnych Prus cztery diecezje: warmińską (dominium biskupów warmińskich), sambijską, chełmińską i pomezańską (w których panowanie sprawowali Krzyżacy) do współczesności, tj. dwóch pierwszych dziesięcioleci XXI wieku. Struktura każdego artykułu hasłowego składałaby się z wyczerpującego biogramu pisarza, obejmującego fakty z jego życia i działalności literackiej (artystycznej), krytycznoliteracki komentarz do twórczości oraz bibliografię podmiotową i przedmiotową.

Najwcześniejszą pracą po 1945 roku, w której znalazły się nazwiska pisarzy, była książeczka, niewielkich rozmiarów, Pisarze olsztyńscy (Olsztyn 1966) opracowana przez Tamarę Wajsbrot i Halinę Kamińską5. Liczyła ona zaledwie 22 strony i obejmowała dziewiętnaście biogramów pisarzy, których losy związały z Olsztynem po 1945 roku. Trzeba przypomnieć, że olsztyński Oddział Związku Literatów Polskich powstał dopiero w 1955 roku i stało się to za sprawą wydania antologii czterech autorów: Michała Lengowskiego, Teofila Ruczyńskiego, Alojzego Śliwy i Marii Zientary-Malewskiej. Były to Poezje Warmii i Mazur (Warszawa 1953). Znalazły się w tym zbiorze wiersze wymienionych autorów - poetów ludowych - napisane często jeszcze przed II wojną światową. Dzięki zaangażowaniu ówczesnego animatora olsztyńskiego życia kulturalnego i literackiego, Władysława Gębika, antologia została wydana w Warszawie i przedstawiona do oceny. W ten sposób pomogła pisarzom najpierw wstąpić w szeregi związku centralnego - warszawskiego, a następnie utworzyć olsztyński oddział ${ }^{6}$.

Wspomniana publikacja pod tytułem Pisarze olsztyńscy miała charakter okolicznościowy i była podsumowaniem 10-letniego okresu funkcjonowania środowiska literackiego w zorganizowany sposób w Olsztynie. Na bazie tego opracowania powstał kolejny słownik, o szerszym zakresie, opracowany przez Edwarda Martuszewskiego, dziennikarza, publicystę, tłumacza i historyka ${ }^{7}$ pod tytułem Wspótcześni pisarze województwa olsztyńskiego (Olsztyn 1972).

5 Pisarze olsztyńscy, oprac. T. Wajsbrot i H. Kamińska, Olsztyn 1966.

6 Szerzej: J. Chłosta-Zielonka, Życie literackie Warmii i Mazur w latach 1945-1989, dz. cyt., s. $72-105$.

7 Szerzej: J. Chłosta-Zielonka, wstęp do Pamiętnika Edwarda Martuszewskiego, Olsztyn 2017, s. 9-29. 
$\mathrm{Na} 186$ stronach przedstawiono sylwetki 52 pisarzy, zawierające opis życia i działalności publicznej oraz bibliografię twórczości i opracowań, ograniczoną do wąskiej przestrzeni czasowej - od lat powojennych do ok. 1970 roku.

Tadeusz Oracki był autorem kolejnego zestawienia zatytułowanego Twórcy i działacze kultury w województwie olsztyńskim w latach 1945-1970. Materiaty biograficzne (Olsztyn 1975). Jak wskazuje tytuł, opracowanie to zawierało krótkie charakterystyki działalności osób, związanych z województwem olsztyńskim w ciągu 25 powojennych lat. W przedmowie napisano: „Książka niniejsza jest pierwszą próbą zebrania informacji o twórcach i pracownikach kultury województwa olsztyńskiego z okresu ćwierćwiecza Polski Ludowej. Jak każde wydawnictwo, tyczące biografii współczesnych, daleka jest od doskonałości"». W pracy wykorzystano także wyniki ankiet, które autor, poprzez Ośrodek Badań Naukowych im. W. Kętrzyńskiego w Olsztynie, rozesłał do 200 wybranych osób. Zawarte tam były pytania o podstawowe dane: wykształcenie, przebieg pracy zawodowej, wykaz ważniejszych prac naukowych i ich omówienie. W publikacji przedstawiono sylwetki blisko 330 osób związanych swoją pracą z regionem, ale trzeba zaznaczyć, że hasła mają bardzo dowolną objętość: od zaledwie kilku zdań po kilka stron.

Największą liczbę haseł osobowych zawierają słowniki biograficzne, które ukazały się w latach 80 . XX wieku, opracowane przez wspomnianego Tadeusza Orackiego: Stownik biograficzny Warmii, Mazur i Powiśla XIX i XX wieku (do 1945 roku) (Warszawa 1983) i Stownik biograficzny Warmii, Prus Ksiażęcych i Ziemi Malborskiej od połowy XV do końca XVIII wieku Olsztyn 1984, tom II, Olsztyn 1988). Ich celem było przedstawienie biografii postaci związanych z wyznaczonym obszarem w różny sposób. Znajdują się więc tutaj biogramy władców, królów, książęta, rycerze, przedstawicieli różnych zawodów, działaczy społecznych. Hasła zbudowane są precyzyjnie, składają się z faktów z życia określonej osoby i zestawienia bibliografii podmiotowoprzedmiotowej, lecz nie zawierają odautorskiego komentarza krytycznego dotyczącego, w przypadku pisarzy, dokonań twórczych.

Dotychczas najważniejszym kompendium wiedzy o pisarzach uprawiających twórczość literacką w środowisku Warmii i Mazur po II wojnie świato-

8 T. Oracki, Twórcy i działacze kultury w województwie olsztyńskim w latach 1945-1970. Materiały biograficzne, Olsztyn 1975, s. 5. 
wej był, opracowywany pod koniec lat 80 . XX wieku, słownik zatytułowany Olsztyńskie biografie literackie 1945-1988 (Olsztyn 1991)9. Powstał jako wynik zbiorowej pracy olsztyńskich badaczy z Wyższej Szkoły Pedagogicznej i Ośrodka Badań Naukowych im. W. Kętrzyńskiego w Olsztynie, prowadzonej pod kierunkiem Jana Chłosty. Zgromadzono w nim blisko sto haseł osobowych współczesnych pisarzy, krytyków literackich, badaczy folkloru, literatury i piśmiennictwa ludowego Warmii i Mazur, zamieszkałych po 1945 roku w województwie olsztyńskim, którzy wydali do momentu publikacji słownika, co najmniej dwie książki lub edytorsko opracowane teksty literackie. Na każde hasło składały się: biogram pisarza, krótka charakterystyka jego dokonań i bibliografia jego twórczości, a także bibliografia przedmiotowa (recenzje, opracowania twórczości). Ponieważ praca ta powstała blisko trzydzieści lat temu, wiele haseł jest już w niej nieaktualnych, gdyż pisarze tam omówieni poszerzyli swoją twórczość. Uzupełnienia domaga się także część bibliograficzna. Trzeba pamiętać, że słownik powstał w czasach, gdy nie istniały media elektroniczne, które umożliwiają dzisiaj dostęp do wszystkich danych.

W XXI wieku opublikowano jeszcze dwa słowniki, których tytuły odnoszą się do obu omawianych krain, Warmii i Mazur. W 2002 roku ukazał się Stownik Warmii (historyczno-geograficzny) ${ }^{10}$ autorstwa Jana Chłosty, a w 2009 roku pod kierunkiem Waldemara Mierzwy, we współpracy z czterdziestoma czterema innymi autorami, powstał stronniczy słownik ilustrowany pod tytułem Mazury ${ }^{11}$.

Celem Słownika Warmii Jana Chłosty było upamiętnienie wskazanej w tytule krainy. Autor od kilkudziesięciu lat jest popularyzatorem wiedzy historycznoliterackiej o Warmii, autorem licznych biografii i tomów wspomnień oraz opracowań, wśród których do najważniejszych należą Prusy Wschodnie w literaturze niemieckiej 1945-1990. Biografie pisarzy (Olsztyn 1993), Spotkania. Wybór reportaży o Warmii i Mazurach z lat 1945-1949 (Olsztyn 1999), opracowany wspólnie z Joanną Szydłowską. Słownik Warmii liczy oko-

\footnotetext{
9 Olsztyńskie biografie literackie 1945-1988, praca zbiorowa pod red. J. Chłosty, Olsztyn 1991.

10 Stownik Warmii, pod red. J. Chłosty, Olsztyn 2002.

11 Mazury. Stownik stronniczy, ilustrowany, pod red. W. Mierzwy, Dąbrówno 2008.
} 
ło 600 haseł - od hasła „Abezier Jan - bp warmiński 1415-1424” do „Żydzi na Warmii". Jest wynikiem dwuletniej, indywidualnej pracy autora, który starał się objąć swoim badaniem, jak sam pisze we wstępie: „biogramy ludzi, Polaków i Niemców, krótkie opisy wsi i dwunastu miast, wydarzeń historycznych i wzmianki o instytucjach, organizacjach, periodykach i wydawnictwach zarówno polskich, jak i niemieckich. Obok tego ukazano świadectwa warmińskości obecnej w dziełach polskich instytucji przed i po 1945 roku oraz ludzi zajmujących się jej rozpowszechnianiem”'12. Słownik ten zawiera też „podstawowe informacje geograficzne o położeniu, faunie i florze, rezerwatach, miejscowościach, ludności, rzekach i jeziorach"13. Wyposażony jest także w wykaz skrótów bibliograficznych, stanowiących zarazem bardzo ciekawą bibliografię omawianego dzieła. Każde zaś hasło posiada dokumentację, w której te skróty zostały wykorzystane. Książkę kończy Spis haset, ułatwiający czytelnikowi dotarcie do interesujących go informacji.

Zupełnie innego rodzaju jest słownik Mazury pod redakcją Waldemara Mierzwy. Jego wartość dokumentacyjna nie ma w nim pierwszorzędnego znaczenia. Sam redaktor thumaczy „stronniczy” charakter publikacji: „Poprosiłem też, aby swoje hasła (autorzy) [...] pisali bez popisywania się wiedzą, bardziej sercem niż rozumem. Encyklopedyczne notki wyszukać można dziś bowiem wszędzie, trudniej znaleźć ich entuzjastycznych czytelników. Zależało mi, żeby autorzy przedstawili swój stosunek do opisywanej osoby, miejsca czy problemu"14. Hasła zawarte w tym słowniku uporządkowane zostały alfabetycznie, ale jest to jedyny rygor narzucony tej publikacji. Nie zadbano w niej o pełną reprezentację tematów, zjawisk, osób, miejsc itp. Każde hasło ma inną budowę, zależną od woli jego autora.

W 2008 roku ówczesny prezes olsztyńskiego oddziału ZLP Józef Jacek Rojek wydał książkę pod tytułem Literaci \& literatura Warmii i Mazur. Przewodnik eseistyczny, w której, kierując się własnym gustem, wiedzą i intuicją przedstawił sylwetki pisarzy, mających jego zdaniem wpływ na życie literackie po 1945 roku w tej krainie. Praca nie ma charakteru naukowo-badawczego i wiele zawartych $\mathrm{w}$ niej ustaleń nie znajduje odzwierciedlenia w materiale

12 Słownik Warmii, dz. cyt.s. 13.

13 Tamże, s. 14.

14 Mazury. Stownik stronniczy, dz. cyt., s. 4. 
źródłowym. Biogramy budowane są za każdym razem według indywidualnej koncepcji autora, bez narzuconego rygoru metodologicznego.

Źródłem aktualnej wiedzy o Warmii i Mazurach mogą być także media elektroniczne. W drugiej dekadzie XXI wieku powstał Leksykon Kultury Warmii i Mazur, czyli multimedialna encyklopedia wiedzy o kulturze regionu. Projekt jest elementem szerszego projektu pod nazwą „Parkowa 2.0”, zrealizowanego przez Centrum Edukacji i Inicjatyw Kulturalnych w Olsztynie przy wsparciu Unii Europejskiej. Jak piszą jego autorzy: „Prace nad Leksykonem zostały podzielone na dwa etapy. W pierwszym z nich, obejmującym okres do końca 2011 roku, utworzyliśmy ponad pięć tysięcy haseł obejmujących okres od 1945 roku do dziś. Drugi etap zaczął się 1 stycznia 2012 roku. Od tego czasu każdy może zostać redaktorem Leksykonu, do czego serdecznie zachęcamy. W 2015 roku zakończyliśmy I etap integracji Leksykonu z Encyklopedia Warmii i Mazur. Ujednolicona została siatka kategorii i wyszukiwarka. Encyklopedia, jako zbiór nadrzędny, obsługuje również bazę Leksykonu Kultury, a w przyszłości Leksykon stanie się integralną częścią Encyklopedii Warmii i Mazur"15. Projekt Encyklopedia Warmii i Mazur to nowoczesny portal informacyjny o charakterze encyklopedycznym, zawierający kompendium wiedzy o Warmii i Mazurach. Centrum Edukacji i Inicjatyw Kulturalnych w Olsztynie zrealizowało w 2015 roku. Na stronie głównej centrum czytamy: „Posiadając doświadczenia w pracy nad Leksykonem Kultury Warmii i Mazur CEiIK stworzyło jedyną w tej skali istniejącą w Polsce encyklopedię regionalną - dostępną za darmo i współtworzoną przez użytkowników. Jako portal jest autoryzowanym źródłem wiedzy i pomocą edukacyjną, a jej zawartość stanowi największy zasób informacyjno-edukacyjny o regionie, dostępny online. Encyklopedia jest wyposażona w szereg stworzonych specjalnie dla tego projektu informatycznych udogodnień, które ułatwiają poruszanie się po zasobach oraz zarządzanie treścią. Pomysłodawcą oraz jednostką odpowiedzialną za realizację projektu jest Centrum Edukacji i Inicjatyw Kulturalnych w Olsztynie. Projekt dofinansowano ze środków unijnych oraz ze środków budżetu Samorządu Województwa Warmińsko-Mazurskiego"16.

15 http://leksykonkultury.ceik.eu/index.php/Strona_g\%C5\%82\%C3\%B3wna [dostęp: 27.12.2019 r.].

$16 \mathrm{http} / /$ www.ceik.eu/projekty/artykul/article/encyklopedia-warmii-i-mazur.html [dostęp: 27.12.2019 r.]. 
Zaprezentowane słowniki i leksykony nie stanowią wyczerpującego źródła wiedzy o wszystkich literatach pochodzących z krainy dzisiaj nazywanej Warmią i Mazurami. Nie uwzględniają wielu haseł osobowych, ze względu na zbyt wąską czasoprzestrzeń: ograniczony zakres badanych lat oraz ogólne, mało precyzyjne traktowanie przestrzeni geograficznej. Hasła nie zawierają pełni danych biograficznych i bibliograficznych, ani też krytycznoliterackiego komentarza. W niektórych pojawiają się błędy merytoryczne. Leksykony elektroniczne są niepełne, ponieważ skatalogowane w nich hasła nie są na bieżąco uzupełniane, podają dane niepełne i często już nieaktualne

Powstanie Stownika pisarzy Warmii i Mazur od czasów najdawniejszych do współczesności umożliwiłoby inwentaryzację wszechstronnej wiedzy o pisarzach związanych z Warmią i Mazurami, a jednocześnie pozwoliło na zrewidowanie sformułowanych niegdyś na temat pisarzy ocen. Narzędzia i metody badawcze wypracowane przez teoretyczne ustalenia nowego regionalizmu: reinterpretacji i rekonceptualizacji, mogą pomóc w analizie i interpretacji dorobku pisarskiego poszczególnych twórców i ukazać go w perspektywie nowych orientacji światowej humanistyki między innymi badań antropologiczno-kulturowych, zwrotu topograficznego i związanej z nim geografii kulturowej, geopoetyki, komparatystyki, a także problematyki pamięci zbiorowej i kulturowej czy postpamięci.

Patronem naukowym badań zmierzających do stworzenia katalogu pisarzy w proponowanej wersji słownika mógłby być Hayden White, autor Przeszłości praktycznej. Badacz postuluje, aby ostrożnie formułować wszelkie formy dotyczące przeszłości, gdyż są one jednocześnie elementem tworzenia nowych treści. Pisanie historii, także historii literatury, a taką formę przyjmie proponowany projekt, łączy się z tworzeniem narracji o faktach historycznoliterackich, a co za tym idzie, ich interpretacją. Każdy układ faktów, takie a nie inne ich zestawienie, zmierza do jakiegoś celu, realizuje jakiś zamiar i łączy się z pewną intencją, którą badacz mimo woli ujawnia. White zdaje sobie też sprawę, że pisanie o przeszłości bez interpretacji - „wyobraźni” historyka - nie ma sensu: „narratywizacja dodaje coś do faktów”17, tworzy dramatyczne ujęcie relacji pomiędzy przeszłością a teraźniejszością.

17 H. White, Przeszłość praktyczna, pod red. E. Domańskiej, przeł. J. Burzyński, A. Czarnacka, T. Dobrogoszcz i in, Kraków 2014, s. 44-66. 
Podstawowym problemem badawczym jest dla Stownika stworzenie przestrzeni geograficznej dla pełnej formuły użytej w tytule. Terytorium nazywane dzisiaj Warmią i Mazurami ma za sobą skomplikowaną historię, której dzieje należy szczegółowo wyjaśnić i zakreślić stosowną mapę, na podstawie której zostanie wyodrębniony zespół nazwisk twórców z nią związanych na przestrzeni wieków. Wskazane krainy choć wywodziły się z jednego pnia - plemion pruskich - miały odrębną historię.

Pierwotnie Warmia stanowiła terytorium pruskiego plemienia Warmów położone nad Zalewem Wiślanym, na długości od Wysoczyzny Elbląskiej (Lanzania) aż do Balgi lub nawet Pokarmina, a także w głąb lądu prawdopodobnie po Łynę. Być może grodem Warmów była również Orneta (pierwotna nazwa Wormditt) położona nad rzeką Drwęcą Warmińską. Południowa część późniejszej Warmii leżała na terytorium innych plemion pruskich - prawdopodobnie Bartów i Galindów. Na mocy decyzji papieża Innocentego IV z 1243 roku w kraju podbijanym przez zakon krzyżacki Warmia należała w latach 1243-1464 do dominium biskupów warmińskich w granicach państwa krzyżackiego, a następnie w latach 1464-1772, czyli do I rozbioru Polski, była Księstwem Warmińskim w obrębie Korony Królestwa Polskiego. Po I rozbiorze została włączona do zaboru pruskiego a ściślej do Królestwa Prus i znalazła się w jego nowo powstałej prowincji Prusy Wschodnie aż do końca I wojny światowej. Wyniki plebiscytu zorganizowanego przez państwa zachodnie w roku 1920 zadecydowały o dalszej przynależności Warmii do Rzeszy Niemieckiej. Warmia była częścią Prus Wschodnich do końca II wojny światowej.

Inna jest historia terytorium Mazur, które obejmowało obszar północno wschodniego wybrzeża, zamieszkiwane było przez kilka plemion pruskich (nazwa Prusy pojawiła się po raz pierwszy w połowie IX wieku w Geografie Bawarskim jako Bruzi) W latach wczesnego średniowiecza tereny Mazur zamieszkiwały plemiona: Pomezanów, Pogezanów, Warmów, Natangów, Galindów, Sasinów, Jaćwingów, Bartów, Sambów, Nadrowów i Skalowów. Mazury, w przeciwieństwie do Warmii, nigdy nie stanowiły odrębnej jednostki administracyjnej ani pod względem kościelnym, ani świeckim, dlatego po części nie da się ustalić ścisłych granic dla Mazur. Wyraźne granice region posiada na odcinkach południowym (graniczy z Mazowszem), wschodnim (graniczy z Podlasiem i Suwalszczyzną) i wzdłuż większości odcinka zachodniego (granice z Warmią oraz Pomorzem, a ściślej ziemią lubawską). Na pozostałych 
odcinkach przechodzi w Barcję, Litwę Mniejszą oraz Prusy Górne. Plemiona pruskie nigdy nie utworzyły jednolitego państwa, co ułatwiło ich podbój przez zakon krzyżacki. Papież Innocenty IV w 1243 wydzielił diecezje: sambijską, chełmińską i pomezańską - w których panowanie sprawowali Krzyżacy. Po pokoju toruńskim kończącym wojnę trzynastoletnią Mazury współtworzyły lenno polskie: Prusy Zakonne do 1525, a następnie świeckie Prusy Książęce. Po podpisaniu traktatów walewsko-bydgoskich (1657 roku) i w wyniku pokoju zawartego między Polską i Szwecją w 1660 roku w Oliwie Fryderyk Wilhelm zwany „Wielkim Elektorem” przestał być lennikiem Polski, stał się suwerennym władcą w Prusach Książęcych. W wyniku koronacji w Królewcu Fryderyka I na króla w 1701 roku w Prusach powstało Królestwo Prus. Konsekwencją I rozbioru Polski w 1772 roku było połączenie Prus z Pomorzem i Brandenburgią. Od tego momentu zaczęły funkcjonować nazwy urzędowe: Prusy Wschodnie i Prusy Zachodnie.

Powstanie II Rzeczypospolitej i przegrana Niemców zapoczątkowały spór o przynależność Mazur. Tak jak na Warmii i Powiślu, także na Mazurach przeprowadzono plebiscyt. Jego niekorzystny wynik zadecydował o przynależności Mazur do Niemiec.

Jeszcze przed końcem II wojny światowej, 14 marca 1945 roku, powstał Okręg Mazurski, który obejmował 27 tys. $\mathrm{km}^{2}$ powierzchni terenów dawnych Prus Wschodnich w granicach z 1939, które zostały włączone do Polski (w tym Powiśle oraz tak zwany subregion EGO), w tym powiaty elbląski, sztumski, kwidzyński i malborski. Siedzibą okręgu był Białystok, a później Olsztyn. 28 czerwca 1946 okręg został rozwiązany i przekształcony w województwo olsztyńskie po uprzednim włączeniu Powiśla (bez powiatu suskiego) w skład województwa gdańskiego, a powiatów ełckiego, gołdapskiego i oleckiego w skład województwa białostockiego. Województwo olsztyńskie w takim kształcie istniało w latach 1946-1975. 6 marca 1950 roku do województwa przyłączono powiat nowomiejski z województwa pomorskiego (przemianowanego tego dnia na bydgoskie) i powiat działdowski z województwa warszawskiego.

Reforma administracyjna Polski w 1975 roku, zmieniająca podział administracyjny Polski, wraz z którą porzucono trójstopniowy podział administracyjny kraju (województwo - powiat - gmina) i zastąpiono go nowym, dwustopniowym podziałem (województwo - gmina), zamiast dotychczasowych 17 województw i pięciu miast wydzielonych wprowadziła 49 województw. 
Z kilku powiatów dotychczasowego województwa olsztyńskiego utworzono województwo ciechanowskie (z powiatu działdowskiego); elbląskie (między innymi z powiatów braniewskiego, pasłęckiego, iławskiego i morąskiego); ostrołęckie (między innymi z powiatu szczycieńskiego); suwalskie (między innymi z powiatu piskiego, giżyckiego, węgorzewskiego i mrągowskiego); toruńskie (między innymi z powiatu nowomiejskiego)

W wyniku reformy podziału administracyjnego kraju w 1999 roku powstało województwo warmińsko-mazurskie i objęło tereny dawnego województwa: olsztyńskiego, większe części województw elbląskiego i suwalskiego oraz fragmenty toruńskiego, ciechanowskiego i ostrołęckiego.

Województwo obejmuje należącą do Polski południową część krainy historycznej Prusy, więc wchodzące w jej skład krainy: Warmia, Mazury, Prusy Górne, ziemia lubawska, Prusy Dolne (południowe części Natangii i Barcji), części Powiśla i Żuław Wiślanych. Południowa i wschodnia granica województwa warmińsko-mazurskiego pokrywa się, w niemal większości miejsc, z dawnymi granicami Prus, a zatem Prus Książęcych i Prus Wschodnich.

Przy powstawaniu Słownika najważniejszym problemem jest sporządzenie listy haseł, które mogłyby się w nim znaleźć. Potrzebne byłyby jasno ustalone kryteria, takie jak: czas w którym pisarz żył i tworzył, przynależność do miejsca, liczba napisanych i wydanych utworów, ich wartość artystyczno-intelektualna, stopień oddziaływania, funkcja społeczna, znaczenie w zachowywaniu ciągłości kulturowej. Hasła osobowe powinny być uporządkowane w sposób tradycyjny, w układzie alfabetycznym, i obejmować związanych w różnym czasie z obszarem Warmii i Mazur twórców łacińskich, niemieckich i polskich oraz pochodzących z innych obszarów językowych. Znaleźć powinni się tu poeci, prozaicy, eseiści, dramaturdzy, krytycy literaccy, autorzy reportaży, wspomnień i pamiętników, tłumacze, badacze literatury, animatorzy życia literackiego. Ponieważ na terenie Warmii najważniejsze znaczenie miała diecezja warmińska utworzona w 1243 roku, to biskupi byli mecenasami sztuki, budowali kościoły i kaplice, fundowali stypendia, ale także sami uprawiali twórczość literacką, na przykład Jan Dantyszek, Stanisław Hozjusz, Marcin Kromer czy Ignacy Krasicki. Z biskupstwem warmińskim związany był także Mikołaj Kopernik. (Szerzej: Stownik biograficzny kapituly warmińskiej, Olsztyn 1996).

Największą grupę powinni stanowić pisarze polscy, którzy znaleźli się po II wojnie światowej na terenach byłych Prus Wschodnich. Byliby to twórcy, 
którzy związali całe swoje życie z tym regionem, tworzyli kolejne instytucje życia literackiego i kulturalnego, najpierw klub literacki, potem od 1955 roku olsztyński Oddział Związku Literatów Polskich, a od 1989 roku także Stowarzyszenie Pisarzy Polskich. Grono ich powinno być poszerzone o pisarzy odwiedzających region w różnych latach, na przykład K. I. Gałczyńskiego, Z. Herberta, J. Iwaszkiewicza, A. Kamieńską, J. M. Gisgesa, J. Parandowskiego, K. Orłosia i wielu innych. W Słowniku pisarzy Warmii i Mazur należałoby umieścić także pisarzy niemieckojęzycznych związanych z tym regionem od wieków: między innymi w okresie reformacji, przed i porozbiorowym, tworzących i mieszkających na Warmii i Mazurach w wiekach XIX i XX: Alfreda Brusta, Johannesa Bobrowskiego, Siegfrieda Lenza, Agnes Miegel, Hermanna Sudermanna, Ernsta Wiecherta, czy też niemieckich pisarzy pochodzenia polskiego, mieszkających dzisiaj w Niemczech, a urodzonych w Polsce po 1945 roku, na przykład Artura Beckera.

Dla utrwalenia kultury narodowej nieodzowne są opracowania kultur i literatur regionów. Tylko wtedy jej obraz i zapamiętany wizerunek będzie pełny. Wzorem dla proponowanego projektu jest Słownik pisarzy śląskich, pod red. Jacka Lyszczyny i Dariusza Rotta, którego pięć tomów powstało w latach 2005-2017 na Uniwersytecie Śląskim. Regiony te - Śląsk oraz Warmia i Mazury, przechodząc w swoich dziejach wiele burzliwych okresów, wykazują także szereg podobieństw, szczególnie na przełomie wieków XIX i XX. W środowisku humanistycznym Warmii i Mazur potrzebne jest podobne wydawnictwo. Badania nad Słownikiem przyczyniłyby się do stworzenia kompendium wiedzy obejmującego szeroki zakres czasowy i zawierającego pełne, uzupełnione biogramy pisarzy. Stanowiłby on bezcenne źródło informacji o funkcjonowaniu pisarzy w życiu literackim nie tylko regionu, ale także kraju, a w przypadku pisarzy niemieckojęzycznych, także w Europie i świecie. Słownik stanowić mógłby punkt wyjścia do badań szczegółowych nad pojedynczymi twórczościami, drogowskaz wskazujący kierunek działań naukowych, inspirację do podjęcia nowych dociekań badawczych opartych o nowe metodologie, którym patronuje nowy regionalizm zakładający rewizję dotychczasowych ustaleń. 
Joanna Chłosta-Zielonka, O potrzebie powstania „Słownika biograficznego pisarzy Warmii i Mazur..."

\section{Bibliografia}

Chłosta J., Warmiak z Podhala: Władysław Gębik pedagog, folklorysta, literat, Olsztyn 2006.

Chłosta-Zielonka J., Życie literackie Warmii i Mazur w latach 1945-1989, Olsztyn 2010.

Martuszewski E., Nawet kamień, Łódź 1965.

Martuszewski E., Mazury i Warmia w literaturze polskiej, Olsztyn 1966.

Martuszewski E., Polscy i niepolscy Prusacy: szkice z historii Mazur i Warmii, Olsztyn 1975.

Mazury. Słownik stronniczy, ilustrowany, pod red. W. Mierzwy, Dąbrówno 2008.

Olsztyńskie biografie literackie 1945-1988, praca zbiorowa pod red. J. Chłosty, Olsztyn 1991.

Oracki T., Twórcy i działacze kultury w województwie olsztyńskim w latach 19451970, Olsztyn 1975.

Pisarze olsztyńscy, oprac. T. Wajsbrot i H. Kamińska, Olsztyn 1966.

Słownik biograficzny Warmii, Mazur i Powiśla XIX i XX wieku (do 1945 roku), pod red. T. Orackiego, Warszawa 1983.

Słownik biograficzny Warmii, Prus Książęcych i Ziemi Malborskiej od połowy XV do końca XVIII wieku, pod red. T. Orackiego, tom I, Olsztyn 1984, tom II, Olsztyn 1988.

Słownik pisarzy śląskich, pod red. J. Lyszczyny i D. Rotta, Katowice, T. I 2005, T. II 2007, T III 2010, T. IV 2013, T. V 2017.

Słownik Warmii, pod red. J. Chłosty, Olsztyn 2002.

Szydłowska J., Narracje pojałtańskiego Okcydentu: literatura polska wobec pogranicza na przykładzie Warmii i Mazur 1945-1989, Olsztyn 2013.

W oczach poetów: Warmia i Mazury 1945-1960, wybrał i oprac. E. Martuszewski, Olsztyn 1960

Warmia i Mazury w oczach poetów 1940-1970, wybr. i oprac. E. Martuszewski, Olsztyn 1972.

White H., Przeszłość praktyczna, pod red. E. Domańskiej, przeł. J. Burzyński, A. Czarnacka, T. Dobrogoszcz i in, Kraków 2014.

Współcześni pisarze województwa olsztyńskiego, pod red. E. Martuszewskiego, Olsztyn 1972. 
Joanna Chłosta-Zielonka, O potrzebie powstania „Słownika biograficznego pisarzy Warmii i Mazur..."

\section{Źródła elektroniczne}

http://leksykonkultury.ceik.eu/index.php/Strona_g\%C5\%82\%C3\%B3wna [dostęp: 27.12.2019 r.].

http://www.ceik.eu/projekty/artykul/article/encyklopedia-warmii-i-mazur.html [dostęp: 27.12.2019 r.]. 